\title{
EDITORIAL
}

\section{PREVENTIVE TRIALS FOR ALZHEIMER'S DISEASES: THE MULTI-DOMAIN AND THE TARGETED THERAPIES APPROACHES WILL HAVE TO BE ASSOCIATED}

\author{
J. LIN ${ }^{1}$, B. DONG ${ }^{1}$, B. VELLAS ${ }^{2}$ \\ 1. The Center of Gerontology and Geriatrics, West China Hospital, Sichuan University, China; 2. Alzheimer's Disease Research and Clinical Center, Gerontopole, UMR 1027, Toulouse, \\ France.
}

Many initiatives are presently on going around the world to prevent dementia. In the US most of the preventive trials are based on biomarkers and targeted drug approach (1-4), in the EU most of the large European funded trials focuses on multidomain intervention $(5,6)$. These different approaches will have probably to joint together in the future. A consensus about the need to treat $\mathrm{AD}$ in the pre-symptomatic phase has emerged following the disappointing results of several trials that enrolled subjects with mild to moderate disease, as well as accumulating research demonstrating that $\mathrm{AD}$ pathologic process begins decades before the appearance of symptoms. Several lessons can be learned from past prevention trials $(7,8)$. The targeted populations were too diverse, the interventions probably not strong enough, and the time of exposure was too short. We have learned from these trials that future prevention trials must be targeted, use strong interventions with known biological activity, and must be sustained with a long-term intervention (9-14). In this editorial, we propose that these prevention trial approaches have to be associated:

The targeted therapy preventive approaches based on biomarker: Preventing AD by targeting a specific population with a specific drug, mostly anti-amyloid. Such preventive approaches and trials are based on biomarkers and imaging to select a study population in accordance with the mechanism of the specific drug. Among these initiatives the Anti-Amyloid Treatment in Asymptomatic Alzheimer's (A4 trial) is the first prevention trial in subjects determined to be at risk based on brain amyloid demonstrated with PET imaging (1). This placebo-controlled trial use solanezumab as the treatment and a composite of well-validate neuropsychological tests known to be sensitive in the early stages of cognitive decline as the primary outcome. The A4 trial aims to exclude older persons without cognitive impairment who, based on the absence of brain amyloid, are much less likely to develop AD. Other trials are targeting a similar population using beta secretase inhibitors. Many current trials are also targeting Pro-dromal Alzheimer's patients with already late MCI and amyloid signature in the brain. Many drugs are presently on trials in this domain mostly monoclonal anti-body and beta secretase inhibitors $(8,15)$. In our point of view a population is missing : those who have early MCI. These individual are not eligible for really preventive trial like A 4 trial because they have some impairment but also not eligible for Pro-dromal Alzheimer because they are not enough impaired (16). All Received July 23, 2015

Accepted for publication December 8, 2015 these cut off are arbitrary and variable, by age , educational level, time of the days, sleepiness.... In our point of view those with early MCI are probably a good target population for preventive trial. Finally this approaches underlined the Suspected non-Alzheimer disease pathophysiology (SNAP). SNAP is a biomarker-based concept that applies to individuals with normal levels of amyloid- $\beta$ biomarkers in the brain, but in whom biomarkers of neurodegeneration are abnormal. The term SNAP has been applied to clinically normal and to mild cognitive impairment subjects. For Jack et al (17) SNAP is present in $23 \%$ of clinically normal individuals aged $>65$ years and in $\sim 25 \%$ of mildly cognitively impaired individuals. $\mathrm{APOE} * \varepsilon 4$ is underrepresented in individuals with SNAP compared with amyloid-positive individuals. Clinically normal and mildly impaired individuals with SNAP have worse clinical and/or cognitive outcomes than individuals with normal levels of neurodegeneration and amyloid- $\beta$ biomarkers (17)

The multi-domain intervention trial approaches $(5,6)$. The idea here is to have a strong intervention adding the effects of several interventions for eg: physical exercise, cognitive exercise, nutrition, optimal treatment of vascular and metabolic risk factors. The rationale for this approach stems from studies showing that several environmental factors are associated with the risk of developing dementia (18-29). These factors may include educational level, vascular and metabolic risk factors, physical activity, cognitive stimulation, and nutritional status (18-29). It may also be possible to identify healthy adults at high risk of $\mathrm{AD}$ and likely to benefit from intervention based on subjective memory complaint, ApoE\&4 carriage, family history of $\mathrm{AD}$, or the presence of frailty; and use multi-domain interventions to compensate for low specificity; Due ot the safety of these intervention long -term trial is feasible.

These both approaches will have to join in the future. What will be probably the future of clinical practice: A preventive approach, integrated into primary care settings that begins with longitudinal monitoring of memory function in a general population with memory complaints or other risk factors to identify decliners, followed by a specific intervention based on biomarkers and imaging discussed case by case. A prevention approach could start by making general recommendations to a large, diverse population (e.g., those age 50 years or older with normal cognition) on diet, physical and cognitive exercise, and risk factor control.

Among those with memory complaints and/or a family 


\section{JNHA: CLINICAL NEUROSCIENCES}

history of dementia, a tailored multi-domain intervention might be proposed, including nutrition, physical and cognitive exercise, and risk factor control, such as was used in the MAPT or FINGER trials $(5,6)$. Ideally, these interventions could be delivered by PCPs who, at the same time, could begin longitudinal monitoring of cognition as a way to identify decliners for the next level of prevention trials.

If subjects with early MCI, biomarkers (e.g., CSF amyloid, tau, as well as PET scans) may be considered. Plasma biomarkers would greatly enhance the ability to conduct large, longitudinal progression studies. At that point, it should be possible to offer multi-domain interventions to those who are biomarker-negative and oral drugs such as anti-amyloid drugs to those who are biomarker positive or those who transition to biomarker positivity during follow-up.

\section{References}

1. Sperling RA, Rentz DM, Johnson KA, Karlawish J, Donohue M, Salmon DP, Aisen P. The A 4 study : stopping AD before symptoms beguin ? Sci Transl Med. 2014 Mar 19;6(228):228fs 13 .

2. Roses AD, Saunders AM, Lutz MW, Zhang N, Hariri AR, Asin KE, et al. New applications of disease genetics and pharmacogenetics to drug development. Current opinion in pharmacology. 2014;14C:81-9.

3. Villeneuve S, Jagust WJ. Imaging Vascular Disease and Amyloid in the Aging Brain: Implications for Treatment. J Prev Alzheimers Dis. 2015 Mar;2(1):64-70. PubMed PMID: 25844350; PubMed Central PMCID: PMC4381867.

4. Cavedo E, Lista S, Khachaturian Z, Aisen P, Amouyel P, Herholz K, Jack CR Jr, Sperling R, Cummings J, Blennow K, O'Bryant S, Frisoni GB, Khachaturian A, Kivipelto M, Klunk W, Broich K, Andrieu S, de Schotten MT, Mangin JF, Lammertsma AA, Johnson K, Teipel S, Drzezga A, Bokde A, Colliot O, Bakardjian H, Zetterberg H, Dubois B, Vellas B, Schneider LS, Hampel H. The Road Ahead to Cure Alzheimer's Disease: Development of Biological Markers and Neuroimaging Methods for Prevention Trials Across all Stages and Target Populations. J Prev Alzheimers Dis. 2014 Dec;1(3):181-202. PubMed PMID: 26478889; PubMed Central PMCID:PMC4606938.

5. Ngandu T, Lehtisalo J, Solomon A, Levälahti E, Ahtiluoto S, Antikainen R, Bäckman L, Hänninen T, Jula A, Laatikainen T, Lindström J, Mangialasche F, Paajanen T, Pajala S, Peltonen M, Rauramaa R, Stigsdotter-Neely A, Strandberg T, Tuomilehto J, Soininen H, Kivipelto M. A 2 year multidomain intervention of diet, exercise, cognitive training, and vascular risk monitoring versus control to prevent cognitive decline in at-risk elderly people (FINGER): a randomised controlled trial. Lancet. 2015 Jun 6;385(9984):2255-63. doi: 10.1016/S0140-6736(15)60461-5. Epub 2015 Mar 12.

6. Vellas B, Carrie I, Gillette-Guyonnet S, Dartigues JF, Touchon J, Dantoine T, et al. MAPT: A multidomain approach for preventing Alzheimer's disease: Design and baseline data. J Prev Alz Dis. 2014;1(1):13-22.

7. Doody RS, Thomas RG, Farlow M, Iwatsubo T, Vellas B, Joffe S, Kieburtz K, Raman R, Sun X, Aisen PS, Siemers E, Liu-Seifert H, Mohs R; Alzheimer's Disease Cooperative Study Steering Committee; Solanezumab Study Group. Phase 3 trials of solanezumab for mild-to-moderate Alzheimer's disease. N Engl J Med. 2014 Jan 23;370(4):311-21. doi: 10.1056/NEJMoa1312889. PMID: 24450890

8. Vellas B, Aisen P, Sampaio C, Brashear HR, Siemers E, Hampel H, et al. Designing Drug Trials for Alzheimer's Disease : What we have learned from the release of the Phase III antibody trials: A Report from the E.U./U.S./C.T.A.D Task Force. Alzheimer's \& dementia.

9. Aisen PS. Cognitive/Clinical Endpoints for Pre-Dementia AD Trials. J Prev Alzheimers Dis. 2015;2(2):82-84. PubMed PMID: 26779453; PubMed Central PMCID:PMC4713036.

10. Marshall GA, Dekhtyar M, Bruno JM, Jethwani K, Amariglio RE, Johnson KA, Sperling RA, Rentz DM. The Harvard Automated Phone Task: new performancebased activities of daily living tests for early Alzheimer's disease. J Prev Alzheimers Dis. 2015 Dec;2(4):242-253. PubMed PMID: 26665121; PubMed Central PMCID: PMC4671513.

11. Atkins AS, Stroescu I, Spagnola NB, Davis VG, Patterson TD, Narasimhan M, Harvey PD, Keefe RS. Assessment of Age-Related Differences in Functional
Capacity Using the Virtual Reality Functional Capacity Assessment Tool (VRFCAT). J Prev Alzheimers Dis. 2015 Jun;2(2):121-127. PubMed PMID: 26618145; PubMed Central PMCID: PMC4657736.

12. Saunders KT, Langbaum JB, Holt CJ, Chen W, High N, Langlois C, Sabbagh M, Tariot PN. Arizona Alzheimer's Registry: Strategy and Outcomes of a Statewide Research Recruitment Registry. J Prev Alzheimers Dis. 2014 Sep;1(2):74-79. PubMed PMID: 26491650; PubMed Central PMCID: PMC4610410.

13. Vellas B, Bateman R, Blennow K, Frisoni G, Johnson K, Katz R, Langbaum J, Marson D, Sperling R, Wessels A, Salloway S, Doody R, Aisen P; Task Force Members. Endpoints for Pre-Dementia AD Trials: A Report from the EU/US/ CTAD Task Force. J Prev Alzheimers Dis. 2015 Jun;2(2):128-135. PubMed PMID: 26247004; PubMed Central PMCID: PMC4523051.

14. Ousset PJ, Delrieu J, Vellas B. Should interventions to treat or prevent Alzheimer's disease be tested in a population or as targeted treatment of highly selected study participants? Alzheimers Res Ther. 2013;5(6):62.

15. Vellas B. Update on Prevention Trials in Alzheimer's Disease The Journal of Prevention of Alzheimer's Disease - JPADC Volume 1, Number 3, 2014 Ppp 168175.

16. Targeting Prodromal Alzheimer Disease With Avagacestat: A Randomized Clinical Trial.Coric V, Salloway S, van Dyck CH, Dubois B, Andreasen N, Brody M, Curtis C, Soininen H, Thein S, Shiovitz T, Pilcher G, Ferris S, Colby S, Kerselaers W, Dockens R, Soares H, Kaplita S, Luo F, Pachai C, Bracoud L, Mintun M, Grill JD, Marek K, Seibyl J, Cedarbaum JM, Albright C, Feldman HH, Berman RM.JAMA Neurol. 2015 Nov 1;72(11):1324-33. doi: 10.1001/jamaneurol.2015.0607.

17. Jack CR Jr, Knopman DS, Chételat G, Dickson D, Fagan AM, Frisoni GB, Jagust W, Mormino EC8, Petersen RC, Sperling RA, van der Flier WM, Villemagne VL, Visser PJ, Vos SJ. Suspected non-Alzheimer disease pathophysiology - concept and controversy. Nat Rev Neurol. 2016 Jan 18. doi: 10.1038/nrneurol.2015.251. [Epub ahead of print]

18. Faux NG, Ellis KA, Porter L, Fowler CJ, Laws SM, Martins RN, et al. Homocysteine, vitamin B12, and folic acid levels in Alzheimer's disease, mild cognitive impairment, and healthy elderly: baseline characteristics in subjects of the Australian Imaging Biomarker Lifestyle study. J Alzheimers Dis. 2011;27(4):909-22.

19. Hooijmans CR, Pasker-de Jong PC, de Vries RB, Ritskes-Hoitinga M. The effects of long-term omega-3 fatty acid supplementation on cognition and Alzheimer's pathology in animal models of Alzheimer's disease: a systematic review and metaanalysis. J Alzheimers Dis. 2012;28(1):191-209.

20. Barberger-Gateau P, Raffaitin C, Letenneur L, Berr C, Tzourio C, Dartigues JF, et al. Dietary patterns and risk of dementia: the Three-City cohort study. Neurology. 2007;69(20):1921-30.

21. Shinto L, Quinn J, Montine T, Dodge HH, Woodward W, Baldauf-Wagner S, et al. A randomized placebo-controlled pilot trial of omega-3 fatty acids and alpha lipoic acid in Alzheimer's disease. J Alzheimers Dis. 2014;38(1):111-20.

22. Ball K, Berch DB, Helmers KF, Jobe JB, Leveck MD, Marsiske M, et al. Effects of cognitive training interventions with older adults: a randomized controlled trial. JAMA. 2002;288(18):2271-81.

23. Wirth M, Haase CM, Villeneuve S, Vogel J, Jagust WJ. Neuroprotective pathways: lifestyle activity , brain pathology, and cognition in cognitively normal older adults. Neurobiol Aging. 2014;35(8):1873-82.

24. Buchman AS, Boyle PA, Wilson RS, Tang Y, Bennett DA. Frailty is associated with incident Alzheimer's disease and cognitive decline in the elderly. Psychosomatic medicine. 2007;69(5):483-9.

25. Kelaiditi E, Cesari M, Canevelli M, van Kan GA, Ousset PJ, Gillette-Guyonnet S, et al. Cognitive frailty: rational and definition from an (I.A.N.A./I.A.G.G.) international consensus group. J Nutr Health Aging. 2013;17(9):726-34.

26. Craft S, Cholerton B, Baker LD. Insulin and Alzheimer's disease: untangling the web. J Alzheimers Dis. 2013;33 Suppl 1:S263-75.

27. Anstey KJ, Eramudugolla R, Hosking DE, Lautenschlager NT, Dixon RA. Bridging the Translation Gap: From Dementia Risk Assessment to Advice on Risk Reduction. J Prev Alzheimers Dis. 2015;2(3):189-198. PubMed PMID: 26380232; PubMed Central PMCID: PMC4568745.

28. Berres M, Kukull WA, Miserez AR, Monsch AU, Monsell SE, Spiegel R. A Novel Study Paradigm for Long-term Prevention Trials in Alzheimer Disease: The Placebo Group Simulation Approach (PGSA): Application to MCI data from the NACC database. J Prev Alzheimers Dis. 2014;1(2):99-109. PubMed PMID: 25530953; PubMed Central PMCID: PMC4268776.

29. Mosconi L, Murray J, Tsui WH, Li Y, Davies M, Williams S, Pirraglia E, Spector N, Osorio RS, Glodzik L, McHugh P, de Leon MJ. Mediterranean Diet and Magnetic Resonance Imaging-Assessed Brain Atrophy in Cognitively Normal Individuals at Risk for Alzheimer's Disease. J Prev Alzheimers Dis. 2014 Jun;1(1):23-32. PubMed PMID: 25237654; PubMed Central PMCID: PMC4165397. 